\title{
Case of impressive megaesophagus in medical intensive care unit
}

\author{
Waqas Aslam, Jorge F Velazco, Shekhar Ghamande
}

Pulmonary, Critical Care \& Sleep Medicine, Baylor Scott and White Central Texas, Temple, Texas, USA

Correspondence to DrWaqas Aslam, Waqas.Aslam@BSWHealth.org

Accepted 26 April 2019

\section{DESCRIPTION}

A 97-year-old woman with a history of hypertension presented to the emergency department after a mechanical fall at home. She had symptoms of retrosternal chest pain and regurgitation for years, probably due to achalasia, which were presumed to be due to gastro-oesophageal reflux disease and treated with proton pump inhibitors. She also reported poor food intake for few weeks prior to hospitalisation due to dysphagia and regurgitation. She had fallen on her right hip while sitting in a chair and right hip radiograph confirmed a subcapital femoral neck fracture. Admission labs were concerning for urinary tract infection and a serum sodium of $122 \mathrm{mEq} / \mathrm{L}$. Hyponatraemia was due to hydrochlorothiazide, prescribed for hypertension and poor food intake due to dysphagia. Preoperative chest radiograph revealed a dilated oesophagus. After a right hip hemiarthroplasty, she developed acute encephalopathy and acute hypoxic and hypercapneic respiratory failure requiring endotracheal intubation and mechanical ventilation, predominantly due to opioid medications prescribed for postoperative pain. Repeat chest radiograph was again concerning for a dilated gas filled oesophagus and oesophageal perforation was considered in differential diagnosis following acute deterioration in patient's condition. A CT of the chest was performed for further evaluation and revealed a markedly dilated oesophagus (figures 1 and 2) and a hiatal hernia. Endoscopy was remarkable for a massively dilated oesophagus with mixed debris, significant maceration and completely closed distal portion of the oesophagus at the level of the lower oesophageal sphincter, consistent with achalasia. Treatment with botulinum toxin was considered but deferred by gastroenterologist due to severely macerated distal oesophagus. After

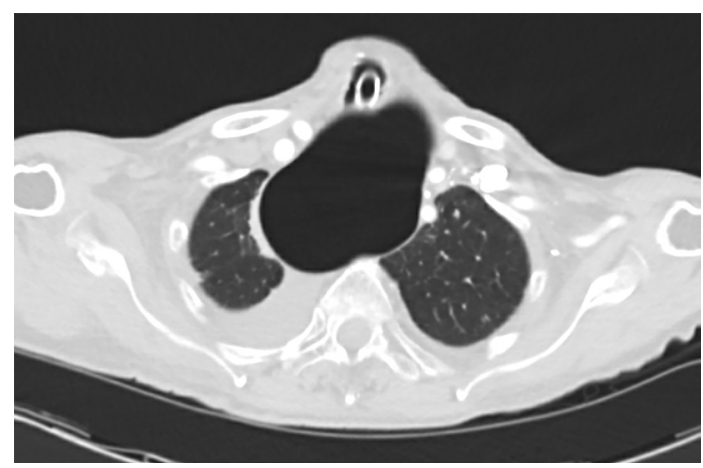

Figure 1 CT chest transverse image showing megaesophagus.

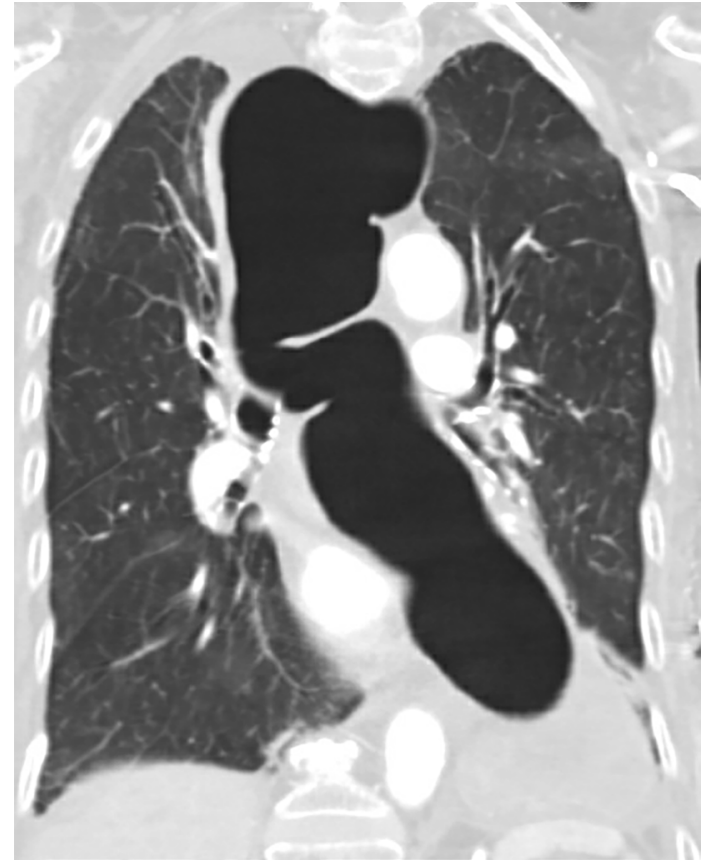

Figure 2 CT chest coronal image showing megaesophagus.

goals of care discussion, the patient's family chose to proceed with a gastrostomy tube for nutrition, which was performed by a push technique. Patient was successfully extubated after 3 days and discharged to a nursing facility. Unfortunately, she passed away few weeks later due to aspiration pneumonia and severe debility.

Achalasia presents with dysphagia for solids and liquids, regurgitation and substernal chest

\section{Learning points}

Achalasia is a motility disorder of the oesophagus characterised by abnormal relaxation of the lower oesophageal sphincter and abnormal peristalsis in the body of oesophagus.

- Achalasia should be treated with appropriate therapy and if left untreated, can lead to progressive severe dilatation of the oesophagus causing megaesophagus, as in our reported case.

- Megaesophagus is associated with increased risk of aspiration pneumonia, severe malnutrition and electrolyte abnormalities, especially in elderly population, leading to significant morbidity and mortality. 
pain. ${ }^{1}$ Manometry is required to establish the diagnosis and considered gold standard. ${ }^{2}{ }^{3}$ Treatment options include botulinum toxin injection, pneumatic dilatation, Heller myotomy and the newly emerging technique per-oral endoscopic myotomy. ${ }^{2-4}$

Contributors WA and SG were involved in direct patient care with full access to the patient data and drafted the initial manuscript. SG and JFV reviewed the manuscript, provided feedback and helped in the final editing of the manuscript.

Funding The authors have not declared a specific grant for this research from any funding agency in the public, commercial or not-for-profit sectors.

Competing interests None declared.
Patient consent for publication Next of kin consent obtained.

Provenance and peer review Not commissioned; externally peer reviewed.

\section{REFERENCES}

1 Pinto J, Pereira F, Banhudo A. Megaesophagus in a patient with achalasia. GE Port J Gastroenterol 2018;26:75-7.

2 Ramchandani M, Nageshwar Reddy D, Nabi Z, et al. Management of achalasia cardia: Expert consensus statements. J Gastroenterol Hepatol 2018;33:1436-44.

3 Smith I, Kahaleh M. An update on current management strategies for achalasia and future perspectives. I Clin Gastroenterol 2018;52:277-86.

4 Ehlers AP, Oelschlager BK, Pellegrini CA, et al. Achalasia treatment, outcomes, utilization, and costs: a population-based study from the United States. J Am Coll Surg 2017:225:380-6.

Copyright 2019 BMJ Publishing Group. All rights reserved. For permission to reuse any of this content visit https://www.bmj.com/company/products-services/rights-and-licensing/permissions/

BMJ Case Report Fellows may re-use this article for personal use and teaching without any further permission.

Become a Fellow of BMJ Case Reports today and you can:

- Submit as many cases as you like

- Enjoy fast sympathetic peer review and rapid publication of accepted articles

Access all the published articles

Re-use any of the published material for personal use and teaching without further permission

For information on Institutional Fellowships contact consortiasales@bmjgroup.com

Visit casereports.bmj.com for more articles like this and to become a Fellow 